\title{
Cultural conditions for basidiospore germination of Lentinus swartzii and Lentinus strigosus and their morphogenesis
}

\author{
Rich Milton R. Dulay ${ }^{1,2}{ }^{*}$, Esperanza C. Cabrera1, Sofronio P. Kalaw ${ }^{2}$, Renato G. Reyes ${ }^{2}$, Ching T. Hou ${ }^{3}$ \\ ${ }^{1}$ Department of Biology, College of Science, De La Salle University, Taft Avenue, Manila, Philippines \\ ${ }^{2}$ Center for Tropical Mushroom Research and Development, and Tuklas Lunas Development Center, Department of \\ Biological Sciences, College of Arts and Sciences, Central Luzon State University, Science City of Munoz, Nueva Ecija \\ 3120 Philippines \\ ${ }^{3}$ National Center for Agricultural Utilization Research, Agriculture Research Service, United States Department of \\ Agriculture, 1815 N. University St., Peoria, Illinois 61604, USA
}

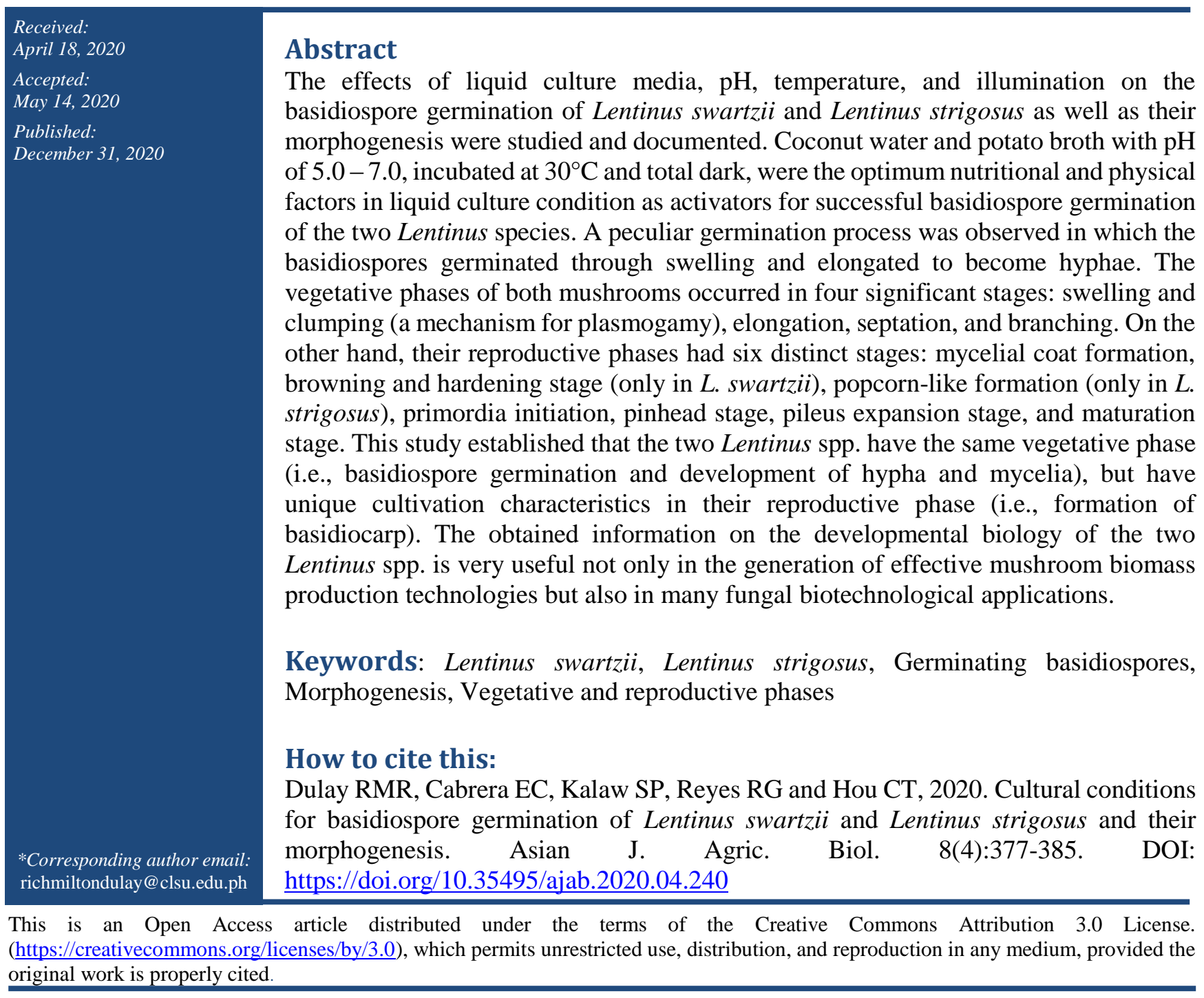




\section{Introduction}

The Philippines is rich in natural resources, which serve as haven for naturally occurring mycoflora. Many kinds of macrofungi have been listed in our ethno-mycological expeditions in different areas of Luzon Island. These wild macrofungi include the genera Ganoderma, Pleurotus, Auricularia, Volvariella, Termitomyces, Coprinopsis, Schizophyllum, Polyporus, Oudemansiella, Trametes, Xylaria, Collybia, and Lentinus. Lentinus, which belongs to Family Polyporaceae, is a group of saprophytic, white-rot basidiomycetous mushrooms that naturally grow on lignin- and cellulosic-rich substrate. This genus has significant position in food industry, enzyme production, effluent treatment and medical application (Manjunathan and Kaviyarasan, 2010). As edible and medicinal macrofungal resource, Lentinus species contain proteins, carbohydrates, sugars, fiber, lipids, and minerals, and exhibit antioxidant, antibacterial, and anti-hyperglycemic activities (Dulay et al., 2014; Dulay and Pamiloza, 2018; Dulay et al., 2015a; Dulay et al., 2015b; Sevindik, 2018). In addition, Kupcova et al. (2018) reported the antimicrobial, anti-inflammatory, antioxidant, and cytotoxic properties of Lentinus edodes. Another study disclosed the antioxidant and cytotoxic activity against cancer cells ( $\mathrm{HeLa}$ and HepG2) of polysaccharide purified from the fruiting body of Lentinus velutinus (Udchumpisai and Bangyeekhun, 2019). Aside from mycelia and fruiting body, extracts of basidiospores and germinating basidiospores of macrofungi have also been reported to demonstrate biological activities (Zhu et al., 2000; Pei-Yu et al., 2012).

With a variety of wild Lentinus species in the Philippines, only four (L. tigrinus, L. sajor-caju, $L$. squarrosulus, L. strigosus) have been isolated and maintained in the laboratory using the optimal culture conditions for mycelial growth, and successfully cultivated in the fruiting bags consisting of rice straw and sawdust formulated substrate in growing house conditions (Cuevas et al., 2009; De Leon et al., 2013; Dulay et al., 2017). Recently, another species, Lentinus swartzii, was isolated and the mycelial nutritional requirements were already established (Dulay et al., 2020). Apart from the optimal cultural conditions for mycelia growth and fruiting body production, the germination of basidiospore and morphogenesis must also be investigated in order to have a better understanding of the fundamental aspects of growth and development of mushroom, which is very essential in a successful production technology. In our previous work, we have demonstrated the optimal conditions for basidiospore germination and morphogenesis of wild strain of $L$. tigrinus, and found out a peculiar germination process and significant developmental stages (Dulay et al., $2012 \mathrm{~b}$ ). Activation and stimulation of basidiospore germination have been reported in various interesting works. For instance, germination of spores of mycorrhizal fungi such as Paxillus involutus, Laccaria laccata, Hebeloma crustuliniforme, Lactarius turpis, and Amanita fulva were stimulated by the plant roots and their exudates (Ali and Jackson, 1988). In their earlier study, the fungus Tritirachium roseum and bacteria Micrococcus roseus, Pseudomonas stutzerin, and Corynebacterium spp. isolated from the sporophores of mycorrhiza, soil, and agar plates as natural contaminants were shown to induce the spore germination of certain mycorrhizal fungi (Ali and Jackson, 1989). Moreover, the application of heat and light wavelength to activate germination of basidiospores of higher basidiomycetes has also been described (Vidyapin et al., 2007; Poyedinok et al., 2015). In addition, treatment of mutagen (methanesulfonate methylester) to basidiospores of Hypsizygus marmoreus generated new mushroom strains (Lee et al., 2011). Thus, investigation of the morphology, germination, morphogenesis, growth and development, variations, and chemical compositions of basidiospores is very vital in the selection of strains for spawn production and in fungal biotechnology research.

In our objective to extend the optimization studies and documentation of the basidiospore germination and basidiocarp formation to other Lentinus species, we investigated herein the L. swartzii and L. strigosus to understand fully their requirements for existence and their developmental biology in our aim to contribute to the efficient cultural management for biomass production.

\section{Material and Methods}

\section{Mushroom strains and basidiospores}

Pure cultures were obtained from our culture collections. Fruiting bodies were produced following the established production technology for the two mushrooms (Dulay et al., 2012a; Dulay et al., 2017). Basidiospores were collected from mature healthy fruiting bodies by laying down on sterile white paper 
in Petri plate and incubated for 12 hours at ambient room temperature to allow the detachment of the basidiospores from the basidium. A portion of paper with basidiospores was aseptically cut using scissors and pre-soaked in test tube containing $9 \mathrm{~mL}$ distilled water. The basidiospore concentration was determined using a haemocytometer and adjusted to $7.5 \times 10^{5} / \mathrm{mL}$. Spore suspensions were incubated in a water bath at $40-50^{\circ} \mathrm{C}$ for $1 \mathrm{~h}$, and $0.1 \mathrm{mg} / \mathrm{ml}$ of streptomycin sulphate was added prior to inoculation.

\section{Evaluation of liquid culture media and pH}

The favorable liquid culture medium for the germination of basidiospores of the two Lentinus was determined. Four indigenous liquid media, namely: coconut water from mature coconut (Cocos nucifera), rice bran D1 (class A) broth (50g of Oryza sativa bran/L of water), yellow corn grit broth $(50 \mathrm{~g}$ of $\mathrm{Zea}$ mays grit/L of water) and potato broth $(250 \mathrm{~g}$ of Solanum tuberosum/L of water) were tested in this study. The liquid media were adjusted to $\mathrm{pH} 6$, and 1 $\mathrm{mL}$ of medium was dispensed into each tube. Three replicates of each medium were prepared. These were sterilized in an autoclave at $121^{\circ} \mathrm{C}, 15$ psi for $30 \mathrm{~min}$. After cooling, the liquid media were inoculated with $0.1 \mathrm{~mL}$ of spore suspension. The inoculated liquid media were incubated at $30^{\circ} \mathrm{C}$ under alternating light and dark conditions. Germination (elongation of the basidiospores) of 100 spores from randomly captured images under a compound microscope was recorded after 7 and $12 \mathrm{~h}$ of incubation. Sampling was done three times from each tube. To determine the optimum $\mathrm{pH}$, the most favorable liquid medium was adjusted to varying $\mathrm{pH}$ levels $(4.0,5.0,6.0,7.0,8.0$, and 9.0) using $1 \mathrm{M} \mathrm{NaOH}$ and $1 \mathrm{M} \mathrm{HCl}$. Liquid media were dispensed into tubes, sterilized, inoculated with 0.1 $\mathrm{mL}$ from the spore suspension, and incubated at $30^{\circ} \mathrm{C}$. Percentage germination was recorded after 7 and $12 \mathrm{~h}$ of incubation.

\section{Evaluation of temperature and illumination}

The most suitable liquid medium and optimum $\mathrm{pH}$ were used to evaluate the influence of temperature and illumination on basidiospore germination. To determine the optimum temperature, inoculated liquid media were incubated in three temperature conditions: $10^{\circ} \mathrm{C}, 20^{\circ} \mathrm{C}$ and $30^{\circ} \mathrm{C}$. On the other hand, for illumination, inoculated liquid media were exposed to artificial white light (322.92 lumens $\left./ \mathrm{m}^{2}\right)$, while the others were maintained in total darkness by covering with black paper, and both were incubated at optimum temperature. Evaluation was done in triplicate. Percentage germination was recorded after $7 \mathrm{~h}$ and 12 $\mathrm{h}$ of incubation. Data were analyzed using Analysis of Variance, and treatment means were compared using Tukey's HSD at 5\% level of significance in the SAS System Version 9.0 (SAS Institute Inc. Cary, NC, USA) program. T-test was used to compare the two illumination conditions.

\section{Documentation of morphogenesis}

Using the established nutritional and physical requirements for basidiospore germination in the optimization study, the germination process and morphogenesis was documented by periodically observing every $2 \mathrm{~h}$ from the time that swelling appeared as observed under a compound microscope. The undergoing swelling, clumping, hyphal fusion, elongation, septation, and branching were observed and photo-documented using a camera. For the developmental stages of basidiocarp formation, fruiting bags were prepared, sterilized, inoculated, and incubated (Dulay et al., 2012a; Dulay et al., 2017). After the full mycelial ramification, fruiting bags were opened and watered to allow the emergence of the basidiocarp. The significant developmental stages from mycelial ramification up to basidiocarp maturation were monitored and photo documented.

\section{Results}

\section{Influence of nutritional and physical factors}

The percentage germination of basidiospores of $L$. swartzii and $L$. strigosus as affected by nutritional and physical factors is presented in Table 1. Interestingly, all liquid culture media evaluated showed stimulatory effect on the germination of basidiospores of the two mushrooms. However, coconut water and potato broth recorded the highest percentage basidiospore germination of $L$. swartzii and L. strigosus in both observation periods. Tukey's HSD revealed no significant difference between the two liquid media in both mushrooms. The optimum $\mathrm{pH}$ of the medium was also determined. Remarkably, basidiospores of both mushrooms germinated at $\mathrm{pH} 4$ to 9 , however, the optimum $\mathrm{pH}$ range was found at $\mathrm{pH} 5$ to 7 . Temperature and illumination significantly influenced the basidiospore germination of the two mushrooms. Noticeably, $30^{\circ} \mathrm{C}$ and total dark significantly recorded the highest percentage basidiospore germination in both mushrooms. 
Table-1. Germination of basidiospores of $L$. swartzii and $L$. strigosus as affected by the nutritional and physical factors after 7 and 12 hours of incubation.

\begin{tabular}{|c|c|c|c|c|}
\hline \multirow{3}{*}{$\begin{array}{l}\text { Nutritional } \\
\text { and Physical } \\
\text { Factors }\end{array}$} & \multicolumn{4}{|c|}{ Basidiospore Germination (\%) } \\
\hline & \multicolumn{2}{|c|}{ L. swartzii } & \multicolumn{2}{|c|}{ L. strigosus } \\
\hline & $\begin{array}{c}7^{\text {th }} \\
\text { Hour }\end{array}$ & $\begin{array}{c}12^{\text {th }} \\
\text { Hour }\end{array}$ & $\begin{array}{c}7^{\text {th }} \\
\text { Hour }\end{array}$ & $\begin{array}{c}12^{\text {th }} \\
\text { Hour }\end{array}$ \\
\hline \multicolumn{5}{|l|}{ Media } \\
\hline Coconut water & $\begin{array}{c}82.00 \pm \\
3.00^{\mathrm{a}}\end{array}$ & $\begin{array}{c}89.33 \pm \\
2.08^{\mathrm{a}}\end{array}$ & $\begin{array}{c}77.00 \pm \\
3.61^{\mathrm{a}}\end{array}$ & $\begin{array}{c}84.00 \pm \\
2.65^{\mathrm{ab}}\end{array}$ \\
\hline Rice bran broth & $\begin{array}{c}68.33 \pm \\
4.04^{\mathrm{b}}\end{array}$ & $\begin{array}{c}80.00 \pm \\
3.61^{\mathrm{b}}\end{array}$ & $\begin{array}{c}77.67 \pm \\
2.52^{\mathrm{a}}\end{array}$ & $\begin{array}{c}82.33 \pm \\
2.08^{b}\end{array}$ \\
\hline Corn grit broth & $\begin{array}{c}71.00 \pm \\
2.65^{\mathrm{b}}\end{array}$ & $\begin{array}{c}77.00 \pm \\
3.61^{\mathrm{c}} \\
\end{array}$ & $\begin{array}{c}68.67 \pm \\
4.04^{\mathrm{b}}\end{array}$ & $\begin{array}{c}76.00 \pm \\
1.73^{\mathrm{c}} \\
\end{array}$ \\
\hline Potato broth & $\begin{array}{c}81.00 \pm \\
3.00^{\mathrm{a}}\end{array}$ & $\begin{array}{c}85.00 \pm \\
2.00^{\mathrm{ab}}\end{array}$ & $\begin{array}{c}79.33 \pm \\
3.51^{\mathrm{a}} \\
\end{array}$ & $\begin{array}{c}86.67 \pm \\
1.53^{\mathrm{a}} \\
\end{array}$ \\
\hline \multicolumn{5}{|l|}{$\mathbf{p H}$} \\
\hline 4.0 & $\begin{array}{c}74.67 \pm \\
1.53^{c}\end{array}$ & $\begin{array}{c}81.33 \pm \\
2.52^{\mathrm{c}}\end{array}$ & $\begin{array}{c}67.67 \pm \\
6.03^{\mathrm{bc}}\end{array}$ & $\begin{array}{c}71.67 \pm \\
4.73^{\mathrm{c}}\end{array}$ \\
\hline 5.0 & $\begin{array}{c}79.67 \pm \\
2.31^{\mathrm{b}}\end{array}$ & $\begin{array}{c}86.33 \pm \\
1.53^{\mathrm{ab}}\end{array}$ & $\begin{array}{c}80.67 \pm \\
2.52^{\mathrm{a}}\end{array}$ & $\begin{array}{c}85.00 \pm \\
2.00^{\mathrm{ab}}\end{array}$ \\
\hline 6.0 & $\begin{array}{c}83.00 \pm \\
1.00^{\mathrm{a}}\end{array}$ & $\begin{array}{c}90.33 \pm \\
2.08^{\mathrm{a}}\end{array}$ & $\begin{array}{c}80.33 \pm \\
1.53^{\mathrm{a}}\end{array}$ & $\begin{array}{c}85.33 \pm \\
1.53^{\mathrm{ab}}\end{array}$ \\
\hline 7.0 & $\begin{array}{c}81.67 \pm \\
2.31^{\mathrm{ab}}\end{array}$ & $\begin{array}{c}87.00 \pm \\
2.00^{\mathrm{ab}}\end{array}$ & $\begin{array}{c}81.67 \pm \\
2.08^{\mathrm{a}}\end{array}$ & $\begin{array}{c}88.33 \pm \\
1.53^{\mathrm{a}}\end{array}$ \\
\hline 8.0 & $\begin{array}{c}73.00 \pm \\
3.00^{\mathrm{c}}\end{array}$ & $\begin{array}{c}77.67 \pm \\
5.69^{c}\end{array}$ & $\begin{array}{c}70.67 \pm \\
4.04^{\mathrm{b}}\end{array}$ & $\begin{array}{c}76.00 \pm \\
3.61^{\mathrm{c}}\end{array}$ \\
\hline 9.0 & $\begin{array}{c}48.67 \pm \\
5.13^{\mathrm{d}}\end{array}$ & $\begin{array}{c}51.00 \pm \\
6.00^{\mathrm{d}}\end{array}$ & $\begin{array}{c}58.33 \pm \\
5.13^{\mathrm{c}}\end{array}$ & $\begin{array}{c}63.00 \pm \\
6.24^{\mathrm{d}}\end{array}$ \\
\hline \multicolumn{5}{|l|}{ Temperature } \\
\hline $30^{\circ} \mathrm{C}$ & $\begin{array}{c}82.67 \pm \\
1.53^{\mathrm{a}}\end{array}$ & $\begin{array}{c}90.00 \pm \\
2.65^{\mathrm{a}}\end{array}$ & $\begin{array}{c}81.33 \pm \\
2.08^{\mathrm{a}}\end{array}$ & $\begin{array}{c}89.67 \pm \\
1.53^{\mathrm{a}} \\
\end{array}$ \\
\hline $20^{\circ} \mathrm{C}$ & $\begin{array}{c}66.33 \pm \\
8.62^{\mathrm{b}}\end{array}$ & $\begin{array}{c}75.33 \pm \\
5.51^{\mathrm{b}}\end{array}$ & $\begin{array}{c}78.67 \pm \\
2.52^{\mathrm{a}}\end{array}$ & $\begin{array}{c}86.33 \pm \\
1.15^{\mathrm{b}}\end{array}$ \\
\hline $10^{\circ} \mathrm{C}$ & $\begin{array}{c}11.33 \pm \\
2.31^{\mathrm{c}}\end{array}$ & $\begin{array}{c}12.33 \pm \\
1.53^{\mathrm{c}}\end{array}$ & $\begin{array}{c}26.33 \pm \\
9.02^{\mathrm{b}}\end{array}$ & $\begin{array}{c}29.67 \pm \\
7.77^{\mathrm{c}} \\
\end{array}$ \\
\hline \multicolumn{5}{|l|}{ Illumination } \\
\hline Lighted & $\begin{array}{c}76.67 \pm \\
3.51^{\mathrm{b}}\end{array}$ & $\begin{array}{c}79.67 \pm \\
3.06^{\mathrm{b}} \\
\end{array}$ & $\begin{array}{c}79.00 \pm \\
1.00^{\mathrm{b}}\end{array}$ & $\begin{array}{c}86.00 \pm \\
1.00^{\mathrm{b}}\end{array}$ \\
\hline Dark & $\begin{array}{c}83.67 \pm \\
1.53^{\mathrm{a}}\end{array}$ & $\begin{array}{c}91.67 \pm \\
1.53^{\mathrm{a}}\end{array}$ & $\begin{array}{c}83.33 \pm \\
1.15^{\mathrm{a}}\end{array}$ & $\begin{array}{c}90.33 \pm \\
1.53^{\mathrm{a}}\end{array}$ \\
\hline
\end{tabular}

Means with the same letters of superscript in each column and factor are not significantly different according to Tukey's HSD $(p<0.05)$. Values are the mean $\pm \mathrm{SD}$ of three replicates.
Morphogenesis from basidiospore to basidiocarp The morphogenesis of the two Lentinus species is shown in Figures 1 and 2. The life cycle is divided into two phases: vegetative phase and reproductive phase. In vegetative phase (basidiospore germination and formation of hypha and mycelia), four significant stages including swelling and clumping, elongation, septation, and branching were observed in both mushrooms. However, these stages appeared differently in the two mushrooms. For instance, elongation appeared after 12-16 hours in L. swartzii and after 11-14 hours in L. strigosus. Branching of mycelia succeeded after 22-36 hours in L. swartzii and after 18-30 hours in L. strigosus. The reproductive phase (development of basidiocarp) had six distinct stages including mycelial coat formation, browning and hardening stage (only in L. swartzii), popcorn-like formation (only in L. strigosus), primordia initiation, pinhead stage, pileus expansion stage, and maturation stage.

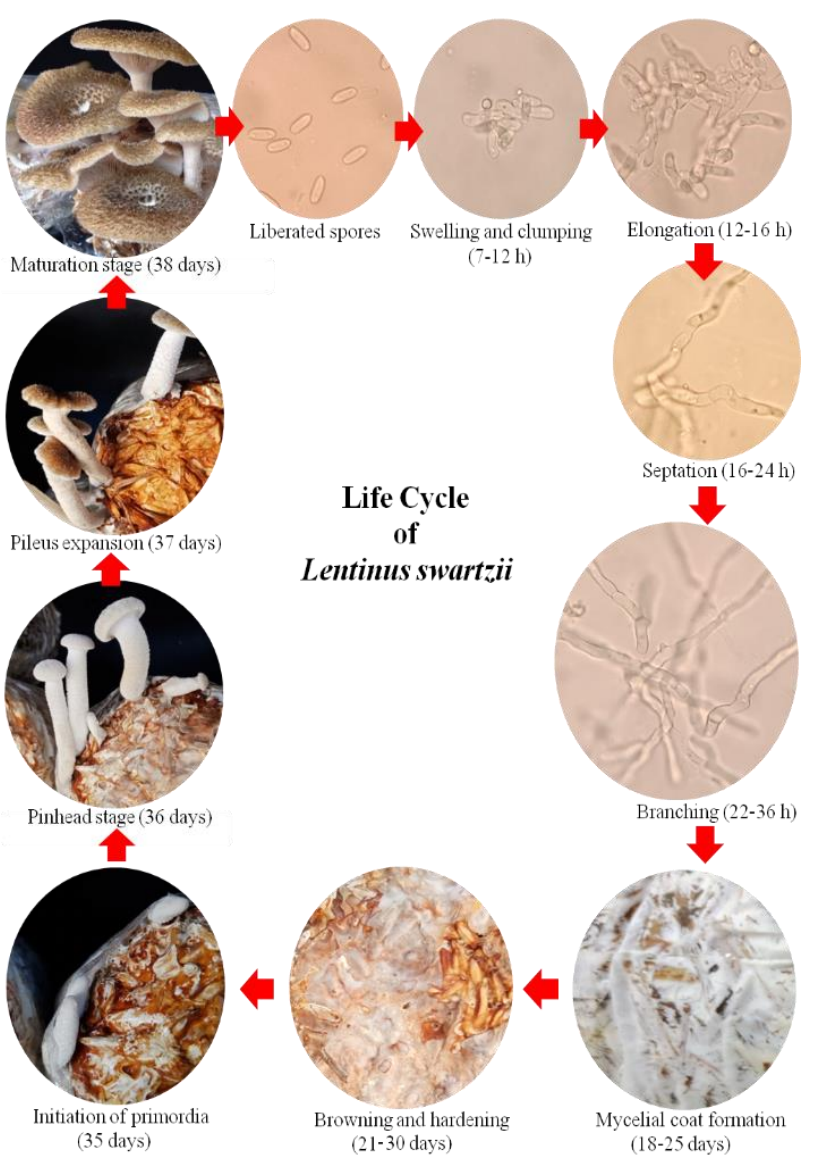

Figure-1. Morphogenesis of Lentinus swartzii. 


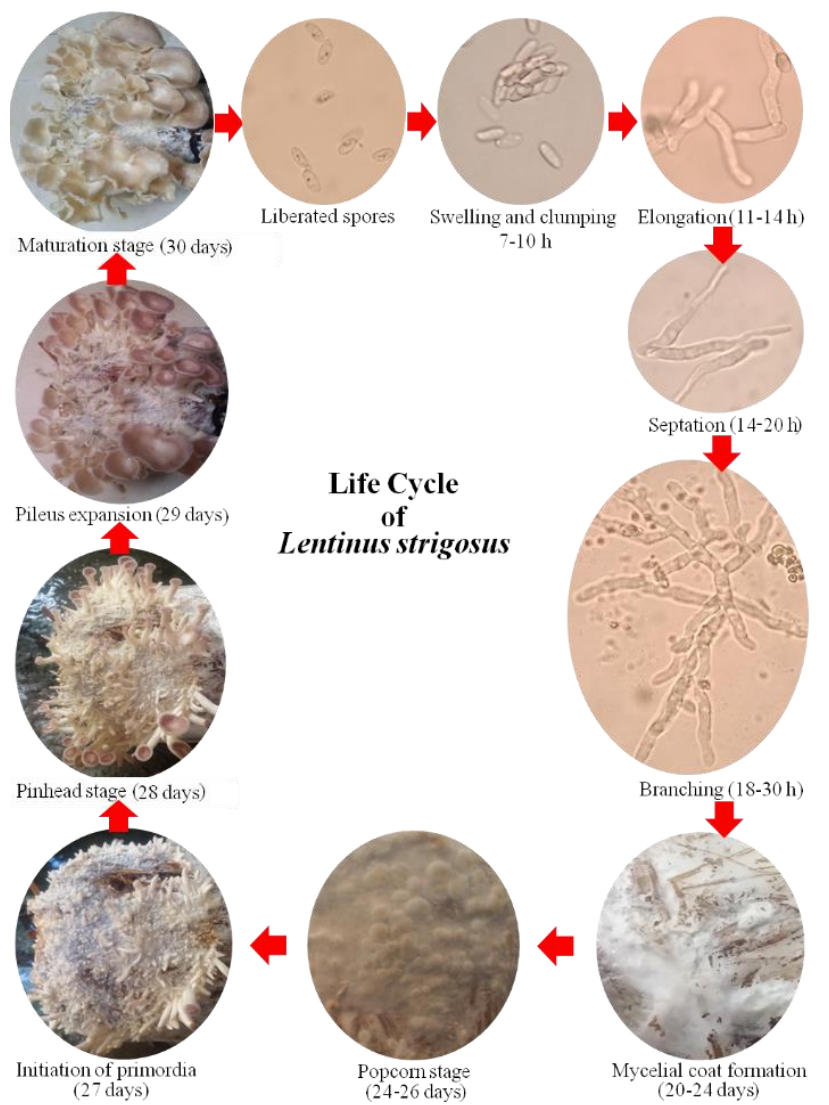

Figure-2. Morphogenesis of Lentinus strigosus.

\section{Discussion}

Basidiospore germination is the beginning of life of any basidiomycetous fungi. Inactive basidiospores turn into active forms by the formation of germ tubes, and differentiate into mycelia. This process could be stimulated by special environmental factors in their natural habitat. Hence, this study investigated the influence of liquid culture media, $\mathrm{pH}$, temperature and illumination on basidiospore germination of the two Lentinus in liquid culture conditions. The present study found out that the liquid culture media used, especially coconut water and potato broth could induce basidiospore germination of $L$. swartzii and $L$. strigosus. Previously, potato broth was identified as the most suitable medium for the germination of basidiospores of L. tigrinus (Dulay et al., 2012b), whereas coconut water was utilized as medium for successful basidiospore germination of Ganoderma lucidum (Magday et al., 2014). The stimulatory effect of the liquid media could be attributed to their nutrient compositions. Borlingame et al. (2009) reported that potato has fructose, sucrose, amylase protein, vitamins such as thiamine, niacin, folic acid and minerals. Coconut water, on the other hand, contains sugars, sugar alcohols, lipids, amino acids, nitrogenous compounds, organic acids, enzymes, vitamins, and minerals (Santoso et al., 1996; Yong et al., 2009). The above-mentioned nutrients were included in the list of nutritional requirements that stimulate basidiospore germination of Schizophyllum commune enumerated by Niederpruem and Dennen (1966).

Apart from the nutrient compositions of the medium or substrate, there are works that demonstrated the use of compound activators. Kikuchi et al. (2007) reported that seven flavonoids including hesperidin, morin, rutin, quercetin, naringenin, genistein, and chrysin have greater stimulating effects compared to the control on basidiospore germination of Suillus bovinus using diffusion gradient assay on water agar plates. Karadeniz et al. (2013) demonstrated that the treatment of basidiospores of $G$. lucidum with hydrogen peroxide for antiseptic purposes also stimulated germination. On the other hand, germination of basidiospores of four Suillus species was induced after exposure to the extracts/exudates from Scotch pine (Pinus sylvestris L) roots. The effect was due to the isolated and identified diterpene resin acid, abietic acid (Fries et al., 1987). The present study successfully demonstrated the utilization of liquid culture media consisting of complex nutrients as one of the effective techniques to induce basidiospore germination of the two Lentinus species. It is necessary, however, to evaluate different nutritional sources (e. g. carbon, nitrogen, minerals, vitamins, etc.) for basidiospore germination in our intention to design a chemically-defined medium for consistent germination rate and process, which is very important in several biotechnological applications and production of mushroom biomass and metabolites.

To assess the effect of $\mathrm{pH}$ on basidiospore germination, coconut water (for $L$. swartzii) and potato broth (for L. strigosus) were adjusted to six $\mathrm{pH}$ levels and inoculated with basidiospores. The optimum $\mathrm{pH}$ range obtained in the present work is slightly lower when compared to the $\mathrm{pH}$ requirements for basidiospore germination of $L$. tigrinus, $S$. commune, and Hebeloma vinosophyllum (Dulay et al., 2012b; Bulseco et al., 2005; Deng and Suzuki, 2008). The low percentage germination at $\mathrm{pH} 9$ indicates that the presence of essential nutrients in coconut water and potato broth is not an indicator to obtain the maximum basidiospore germination, it is also dependent on the favourable $\mathrm{pH}$ of the medium. It is 
interesting to note that the optimum $\mathrm{pH}$ for mycelial growth of $L$. strigosus that we previously reported (Dulay and Garcia, 2017) is within the optimum pH range for the germination of its basidiospores obtained in this work. The results of the present study strongly suggest that $\mathrm{pH}$ is an important factor in the medium that significantly influenced the germination of basidiospores.

After establishing the most favorable liquid culture media and optimum $\mathrm{pH}$, it is also necessary to assess the effects of environmental physical factors such as temperature and illumination. Incubation at $30^{\circ} \mathrm{C}$ and total dark were found to be the optimum physical conditions for basidiospore germination of both Lentinus. The results suggest that temperature and illumination are also significant, thus, incubation at $30^{\circ} \mathrm{C}$ and total dark could be used as technique to stimulate germination of basidiospores of the two Lentinus species. Similarly, basidiospores of most crosses of Cryptococcus gattii showed significantly higher germination rates at $30^{\circ} \mathrm{C}$ than at $23^{\circ} \mathrm{C}$ (You and $\mathrm{Xu}, 2018$ ). However, the present result does not agree with the reported optimal temperature of $L$. tigrinus, $S$ commune, and $P$. ostreatus, which is at $23^{\circ} \mathrm{C}$ to $28^{\circ} \mathrm{C}$ (Dulay et al., 2012b; Bulseco et al., 2005; Lin, 2004). In addition, Coprinus radiatus had significantly greater proportion of germinated basidiospores at higher temperature of $45^{\circ} \mathrm{C}$ than at $30-35^{\circ} \mathrm{C}$ (Mills and Eilers, 1973). Based on these findings and our results, it is safe to say that higher basidiomycetes have diverse germination rates as they respond to certain temperature. You and Xu (2018) explained that this diversity might be related to mitochondrial inheritance patterns that are affected by environmental factors such as temperature, which may influence spore viability and energy generation. Moreover, this is also due to variation and uniqueness of individual fungal species and strain.

Although light is an important morphogenetic factor in most macrofungi, the present study proved the inhibitory effect of light on basidiospore germination of the basidiomycetes. The same response was also observed on the vegetative mycelial growth of $L$. strigosus (Dulay and Garcia, 2017). However, present results contradict our previous observations in $L$. tigrinus (Dulay et al., 2012b). Moreover, Poyedinok et al. (2015) reported the stimulating effects of light wavelengths and coherence on basidiospore germination. The most suitable conditions were red coherent and incoherent light of $632.8 \mathrm{~nm}$ and 660,0 $\mathrm{nm}$ for Agaricus bisporus, Ganoderma applanatum,
$P$. ostreatus, red and blue coherent light of $632.8 \mathrm{~nm}$ and 488,0 nm for Flammulina velutipes, G. lucidum and Hericium erinaceus, and both red and blue laser and light-emitting diode (LED) light for Lentinula edodes. In addition, spore germination of Pleurotus sapidus was strongly inhibited by white and blue lights, but not by red and yellow lights (McCracken, 1982). These findings clearly indicate that the response of basidiospores of several species and strains to light in terms of germination may be either stimulatory or inhibitory. Therefore, germination of basidiospores is not only necessarily dependent on the nutritional attributes and $\mathrm{pH}$ of the culture media but also on the combined influence of physical environmental factors such as temperature and illumination.

Since the present work demonstrated the successful germination of basidiospores of $L$. swartzii and $L$. strigosus in their most suitable liquid culture medium and optimum physical conditions, it was therefore necessary to document the germination process and morphogenesis to fully understand their developmental biology, which is very vital in the generation of efficient biomass production technologies. The vegetative and reproductive phases of both mushrooms were studied. The vegetative phases of both mushrooms occurred in four significant stages: swelling and clumping, elongation, septation, and branching. It is interesting to note that the two Lentinus had different period of appearance of the above-mentioned stages. The germination process was found faster in L. strigosus than in L. swartzii. Fries (1984) reported that the period and rate of germination vary depending on species and strain type, among different basidiocarps, and even among different parts of the hymenium. Basidiospore is said to be germinating when a germ tube emerges from the hilum, which is common in Volvariella volvacea (Reyes, 1999). However, in this study, a peculiar type of germination process was observed. Liberated basidiospores of the two Lentinus germinated through swelling and elongation, where the basidiospore coat became part of the hypha. Clumping or grouping of germinating basidiospores was also evidently observed, which is probably a mechanism for plasmogamy or hyphal fusion. The basidiospores continuously elongated and formed septa to become hyphae, then into primary mycelia. After the course of plasmogamy (dikaryotization), primary mycelia developed into secondary mycelia. In prolonged incubation in liquid culture, massive branching of 
mycelia continuously occurred until the formation of thick mycelial mat on the surface of the medium, which indicates a very promising alternative of mycelial biomass production from the basidiospores origin.

To document the reproductive phase (basidiocarp formation) of life cycle, substrates in fruiting bags were inoculated and incubated to allow mycelial ramification. After 18-25 days (for L. swartzii) and 20-24 days (for L. strigosus) from the day of inoculation, the entire substrate was fully colonized by mycelia and thick mycelial coats were formed. In $L$. strigosus, thick mycelial coats developed into popcorn-like swellings after 2-4 days, then into primordia (fruiting initials) after the fruiting bags were opened and watered. However, in L. swartzii, popcorn-like swellings were not observed. Instead, browning and hardening appeared after 3-5 days from the mycelial coat formation and after exposure to water. Then, from brown and hardened mycelia, the primordia initiated after 5 days. In contrast, browning and hardening stage was not observed in L. stigosus. However, both popcorn stage and browning stage were documented in L. tigrinus (Dulay et al., 2012b). The primordia continuously elongated to become the stipe and formed a broad button-like tip, the young pileus. The in-rolled downward margin of young pileus expanded into mature pileus. The dark brown young pileus of $L$. swartzii turned into light brown, scaly, hairy mature pileus, while the purple young pileus of L. strigosus became pale, hairy, mature pileus. The lamellae or gills underneath the mature pileus produced the numerous basidiospores to be liberated and dispersed for the perpetuation of the species.

The present work has shown the successful germination of basidiospores of $L$. swartzii and $L$. strigosus in liquid culture using nutrient-rich indigenous media, varying $\mathrm{pH}$ levels, temperature, and illumination. The processes of basidiospore germination and hypha and mycelial development of the two evaluated Lentinus spp. discussed in the preceding section are very similar to those of $L$. tigrinus, which, to our knowledge, is the first studied Lentinus species for basidiospore germination and morphogenesis. This peculiar germination process could be very valuable in the confirmation of identity of certain species if belonging to genus Lentinus. It is noteworthy to mention that the two Lentinus spp. have unique cultivation characteristics in the formation of basidiocarp as indicated by the nonappearance of popcorn stage in L. swatzii and browning and hardening stage in L. strigosus. This study on morphogenesis and cultivation phases established that L. strigosus is a fast-growing species.

\section{Conclusion}

In conclusion, this study demonstrated the effects of culture media, $\mathrm{pH}$, and physical factors such temperature and illumination on the basidiospore germination of $L$. swartzii and L. strigosus. Liquid culture using coconut water and potato broth with a $\mathrm{pH}$ of 5 to 7 at $30^{\circ} \mathrm{C}$ and dark condition is an effective technique to activate and stimulate germination of the basidiospores. It has also been established that the vegetative phase occurs in four significant stages while the reproductive phase has six distinct stages in both mushrooms. Popcorn stage and browning stage appeared individually but not concurrently in each life cycle. The obtained data provide basic information on the developmental biology of the two Lentinus species, which is highly utilizable in the development of practical, innovative, and effective technologies for the management of cultures, commercial production of mushroom biomass, and hybridization and selection of strains. For consistency of the germination rate and process, it is worthy to further investigate the influence of different nutrient sources in order to design a chemically defined medium. Elucidation of chemical compositions and biological activities of basidiospores, germinating basidiospores, basidiospore-derived mycelia, and spent liquid culture medium is of scientific and practical interest.

\section{Acknowledgment}

The authors would like to thank the Department of Science and Technology - Science Education Institute (DOST-SEI) in the Philippines for the scholarship grant for Mr. Rich Milton R. Dulay who is pursuing $\mathrm{PhD}$ in Biology at De La Salle University-Manila, Philippines.

Disclaimer: None.

Conflict of Interest: None. Source of Funding: None. 


\section{References}

Ali NA and Jackson RM, 1988. Effects of plant roots and their exudates on germination of spores of ectomycorrhizal fungi. Transact. Brit. Mycol. Soc. 91(2): 253-260.

Ali NA and Jackson RM, 1989. Stimulation of germination of spores of some ectomycorrhizal fungi by other micro-organisms. Mycol. Res. 93(2): 182-186.

Borlingame B, Mouille B and Charrondiere R, 2009. Nutrients, bioactive non nutrients and antinutrients in potatoes. J. Food. Compost. Anal. 22: 494-502.

Bulseco MG, Abella E and Reyes RG, 2005. Morphogenesis of Schizophyllum commune, a wild edible mushroom of Mt. Nagpale, Abucay, Bataan, Philippines. J. Nat. Stud. 4(1): 20-28.

Cuevas MJ, Reyes R and Kalaw S, 2009. Biophysiology of Lentinus sajor-caju. J. Trop. Biol. 7: 48.

De Leon AM, Reyes RG and Dela Cruz TEE, 2013. Lentinus squarrosulus and Polyporus grammocephalus: newly domesticated, wild edible macrofungi from the Philippines. Philipp. Agric. Sci. 96(4): 411-418.

Deng $\mathrm{Z}$ and Suzuki A, 2008. Effects of pH, NH4-N concentration, temperature, and storage period on basidiospore germination in an ectomycorrhizal ammonia fungus Hebeloma vinosophyllum. Mycoscience. 49(3): 178-184.

Dulay RMR, Arenas MC, Kalaw SP, Reyes RG and Cabrera EC, 2014. Proximate composition and functionality of the culinary-medicinal tiger sawgill mushroom, Lentinus tigrinus (Higher basidiomycetes), from the Philippines. Int. J. Med. Mushrooms. 16(1): 85-94.

Dulay RMR, Cabrera EC, Kalaw SP, Reyes RG and Hou CT, 2020. Nutritional requirements for mycelial growth of three Lentinus species from the Philippines. Biocatal. Agric. Biotechnol. 23: 101506.

Dulay RMR, Cabrera EC, Kalaw SP and Reyes RG, 2012b. Optimal growth conditions for basidiospore germination and morphogenesis of Philippine wild strain of Lentinus tigrinus (Bull.) Fr. Mycosphere. 3(6): 926-933.

Dulay RMR, Flores KS, Tiniola RC, Marquez DHH, Dela Cruz AG, Kalaw SP and Reyes RG, 2015b. Mycelial biomass production and antioxidant activity of Lentinus tigrinus and Lentinus sajor- сајu in indigenous liquid culture. Mycosphere. 6(6): 659-666.

Dulay RMR and Garcia EJB, 2017. Optimization and enriched cultivation of Philippine (CLSU) strain of Lentinus strigosus (BIL1324). Biocatal. Agric. Biotechnol. 12: 323-328.

Dulay RMR, Kalaw SP, Reyes RG, Cabrera EC and Alfonso NF, 2012a. Optimization of culture conditions for mycelial growth and basidiocarp production of Lentinus tigrinus (Bull.) Fr., a new record of domesticated wild edible mushroom in the Philippines. Philipp. Agric. Sci. 95: 278-285.

Dulay RMR and Pamiloza DG, 2018. Proximate composition and bioactivities of hairy sawgill mushroom, Lentinus strigosus (BIL 1324) from the Philippines. Int. J. Biol. Pharm. Allied Sci. 7(3): 361-369.

Dulay RMR, Ray K and Hou CT, 2015a. Optimization of liquid culture conditions of Philippine wild edible mushrooms as potential source of bioactive lipids. Biocatal. Agric. Biotechnol. 4: 409-415.

Dulay RMR, Rivera AGC and Garcia EJB, 2017. Mycelial growth and basidiocarp production of wild hairy sawgill Lentinus strigosus, a new record of naturally occurring mushroom in the Philippines. Biocatal. Agric. Biotechnol. 10: 242246.

Fries N, 1984. Spore germination in the higher basidiomycetes. Proc. Indian Acad. Sci. (Plant Sci.). 93(3): 205-222.

Fries N, Serck-Hanssen K, Dimberg LH and Theander O, 1987. Abietic acid, and activator of basidiospore germination in ectomycorrhizal species of the genus Suillus (Boletaceae). Exp. Mycol. 11(4): 360-363.

Karadeniz E, Sarigullu FE and Untac I, 2013. Isolation and germination of Ganoderma lucidum basidiospores and effect of $\mathrm{H}_{2} \mathrm{O}_{2}$ on the germination of spores. J. Food Agric. Environ. 11(1): 745-747.

Kikuchi K, Matsushita N, Suzuki K and Hogetsu T, 2007. Flavonoids induce germination of basidiospores of the ectomycorrhizal fungus Suillus bovinus. Mycorrhiza. 17(7): 563-570.

Kupcova K, Stefanova I, Plavcova Z, Hosek J, Hrouzek $\mathrm{P}$ and Kubec R, 2018. Antimicrobial, cytotoxic, anti-inflammatory, and antioxidant activity of culinary processed shiitake medicinal mushroom (Lentinus edodes, Agaricomycetes) and its major sulfur sensory-active compound lenthionine. Int. J. Med. Mushrooms. 20(2): 165-175. 
Lee J, Kang HW, Kim SW, Lee CY and Ro HS, 2011. Breeding of new strains of mushroom by basidiospore chemical mutagenesis. Mycobiology. 39(4): 272-277.

Lin Z, 2004. Substrate Grass (Juncao), pp. 107-113. In MushWorld (eds.), Mushroom Growers Handbook 1: Oyster mushroom cultivation. MushWorld-Heineart Inc., Seoul, Korea.

Magday Jr. JC, Bungihan ME and Dulay RMR, 2014. Optimization of mycelial growth and cultivation of fruiting body of Philippine wild strain of Ganoderma lucidum. Curr. Res. Environ. Appl. Mycol. J. Fungal Biol. 4(2): 162-172.

Manjunathan K and Kaviyarasan V, 2010. Biotechnological applications of Lentinus tuberregium (Fr).; a South Indian edible mushroom. Eur. J. Biol. Sci. 4(1): 28-31.

McCracken FI, 1982. Some factors affecting basidiospore germination of Pleurotus sapidus. Can. J. Bot. 60: 1658-1661.

Mills GL and Eilers FI, 1973. Factors influencing the germination of basidiospores of Coprinus radiatus. J. Gen. Microbiol. 40: 269-273.

Niederpruem DJ and Dennen DW, 1966. Kinetics, nutrition and inhibitor properties of basidiospore germination in Schizophyllum commune. Arch. Microbiol. 54(2): 91-105.

Pei- $\mathrm{Yu} \mathrm{H}$, Jiun-Liang $\mathrm{CH}$, Hsing-Hu $\mathrm{CH}$ and SienHung Y, 2012. Extract of sporoderm-broken germinating spores of Ganoderma lucidum activates human polymorphonuclear neutrophils via the P38 mitogen activated protein kinase pathway. Chang Gung Med. J. 35(2): 140-148.

Poyedinok N, Negriyko A and Mikhailova O, 2015. Effects of light wavelengths and coherence on basidiospores germination. J. Microbiol. Biotechnol. Food Sci. 4(4): 352-257.

Reyes RG, 1999. Basic and applied studies for the cultivation of paddy straw mushroom (Volvariella volvacea) from the Philippines. Ph.D. dissertation, Tokyo University of Agriculture, Japan.

Santoso U, Kubo K, Ota T, Tadokoro T and Maekawa A, 1996. Nutrient composition of kopyor coconuts (Cocos nucifera L.). Food Chem. 57:
299-304.

Sevindik M, 2018. Investigation of antioxidant/oxidant status and antimicrobial activities of Lentinus tigrinus. Adv. Pharmacol. Sci. Article ID 1718025: 4 pages.

Udchumpisai W and Bangyeekhun E, 2019. Purification, structural characterization, and biological activity of polysaccharides from Lentinus velutinus. Mycobiology. 48: 51-57.

Vidyapin VI, Zharikova GG, Nefelova MV, Zharikova EN, Kozmina AO and Stasevych VM, inventors. 2007. Method of higher mushroom basidiospores germination. RU Patent 2,188,537.

You M and Xu J, 2018. The effects of environmental and genetic factors on the germination of basidiospores in the Cryptococcus gattii species complex. Sci. Rep. 8: 15260.

Yong JWH, Ge L, Ng YF and Tan SN, 2009. The chemical composition and biological properties of coconut (Cocos nucifera L.) water. Molecules. 14: 5144-5164.

Zhu HS, Yang XL, Wang LB, Zhao DX and Chen L, 2000. Effects of extracts from sporoderm-broken spores of Ganoderma lucidum on HeLa cells. Cell Biol. Toxicol. 16(3): 201-206.

\section{Contribution of Authors}

Dulay RMR: Contributed in conceptualization of the study, data collection, literature review search, experimental design and data interpretation and manuscript writing

Cabrera EC: Contributed in conceptualization of the study, research design and methodology assessment, manuscript critiquing and final approval

Kalaw SP: Contributed in statistical analysis, data interpretation and analysis and final reading Reyes RG: Contributed in research design, methodology assessment and final reading Hou CT: Contributed in research design, methodology assessment and manuscript critiquing 